\title{
Preface to the 2005 Edition
}

To be underdeveloped is to be poor. It is also to be agrarian. Markets and States in Tropical Africa represents an effort to comprehend the economics of development by analyzing the politics of agrarian societies.

The book also addresses development in Africa. Preparing to write this book, I traveled in Kenya, Ghana, Tanzania, Nigeria, and Zambia, where I abstracted notes from policy documents, pored over government reports and newspaper collections, and gathered data on prices in major agricultural markets. I also interviewed ministers and farmers and traveled from shambas to port cities in an effort to trace the market chain of major agricultural commodities.

Everywhere, I found the optimism that had greeted independence giving way to disillusion. Growth rates that had averaged over 2 percent at the start of the 1970s had fallen nearly to 0 percent by the time I began my research; by the time of the book's publication, they had begun to turn negative. And whereas 20 percent of the forty-six states of sub-Saharan Africa contained competitive party systems in 1970 , only 7 percent did so in the mid-1970s. In their place now stood authoritarian regimes, some disguised as single party systems and others transparently dictatorial. 


\section{xii Preface to the 2005 Edition}

When addressing the sources of Africa's decline, I made two decisions that imparted a distinctive character to this book. The first was to assume that farmers-even peasant farmers-respond to economic incentives. I was willing to make this assumption because, having lived in village communities, I knew it to be true. The second was that the governments of Africa could take actions that shaped these incentives and thereby the performance of their economies. The first decision led me toward what was becoming known as the rational choice school of political science. The latter diverted my attention from the position of Africa's economies in the global economic system to the influence of political and social forces within them. I thus separated myself from the so-called dependency school of development, which was then the dominant paradigm.

\section{THE APPROACH}

Looking back, I now recognize how radical was the decision to focus on internal rather than international determinants of development. While I was probing the impact of internal sources of underdevelopment, global forces were inflicting staggering blows from without. In the early 1970 s, prices for food crops rose dramatically in global markets, driven upward by the depreciation of the dollar and the entry of Russia into global food markets. El Niño struck with devastating force in the mid-1970s, driving up the price of grain exports from North America on the one hand while producing drought in Africa on the other; Africa's need for food crops thus spiked upwards just as the price of food in global markets rose. Then in the late 1970s, the oil price shocks and the rise of interest rates provoked a major worldwide recession, resulting in a decline of demand in the advanced industrial nations for agricultural exports from Africa.

Had I taken these forces into account, I would not have abandoned my examination of the internal determinants of policy choice in Africa. But I would have posed different questions. Recognizing the magnitude and malevolence of the external shocks, I would have asked why the governments responded, or failed to respond, to them in the ways they did. Why did they fail to adjust their exchange rates when the dollar fell in value? Why did they continue to invest in unproductive domestic industries when the rate of return on such invest- 
ments had declined so greatly relative to the opportunity costs of capital? Why did they pass on so much of the fall in export earnings to the farmer, rather than assuming a larger portion of the risks originating in foreign markets? And why, in response to these shocks, did the economies of Africa sink so far and fall so hard in comparison to those of other regions?

\section{THE PUBLIC RECEPTION}

Because it emphasized the economic costs of government policies, Markets and States in Tropical Africa resonated with the ideological debates of its time. Proponents of Reaganomics and Thatcherism saw in the book justification for their belief that governments were part of the problem, rather than part of the solution, to the poor performance of Africa's economies. The World Bank released the famed Berg Report in 1981, the same year that the University of California Press published Markets and States, and the contributions of the one strengthened the impact of the other. The World Bank's data provided confirmation of the patterns of market intervention that I described and of the magnitude of their impact upon producer incentives. And Markets and States helped to explain why governments might choose to intervene in this manner. The report's call for a reduction in the role of governments marked the entry of ReaganThatcherist thinking into development institutions-and, I fear, of my writing into the emerging orthodoxy now known as the Washington Consensus.

More surprising was the reaction within Marxism, whose ranks were then becoming increasingly divided. Prior to the rise of the newly industrialized nation of Brazil, the dependency theorists held sway. Vocal members of that school held that the underdevelopment of the "South" resulted from the dominance of the "North" in global markets. International exploitation, they argued, retarded the spread of capitalist forms of production and the growth of the developing world.

Marxists who believed that capitalism would and could transform all societies dissented from this analysis. The implication of their position was that class formation and class conflict would occur everywhere, even in the least developed nations. Markets and States appeared 
to confirm their vision of internal patterns of inequality within the developing world and to offer insight into the mechanisms by which exploitation took place. Africa's development crisis thus became emblematic of underdevelopment, as its political leaders diverted resources from productive investment to elite consumption.

\section{THE ACADEMIC RECEPTION}

With the end of the Cold War and the collapse of the Soviet Union, the din resounding about such controversies became muted. Markets and States continues to be used in academic courses, however, largely because it advances a mode of reasoning now known as the "rational choice" approach to the study of politics.

I was converted to this approach by my experiences in the field. The villagers among whom I had lived were canny strategists, I found. They were assertive rather than deferential, surprisingly well informed about national and international politics, and fully cognizant of their interests. In only one relevant respect did they differ from us in the developed world: nature had dealt them a lousy set of cards. Recognizing this reality, I abandoned the approach that I had studied as a graduate student-the modernization school, with its appeal to culture and its reliance upon psychology-and turned to forms of theory based on the presumption of rationality and the importance of choice.

Upon its introduction to development studies, the rational choice school was attacked for its apparent endorsement of the ethical virtues of the allocations achieved in competitive markets. Devotees of the public choice tradition certainly endorse this position, and some located Markets and States within that school. In Markets and States, however, I employed the market allocation as a baseline from which to infer the impact of political forces rather than to judge the ethical quality of outcomes. I also emphasized what was patently true: that competitive markets would generate prices for African peasants higher than those offered by their governments. In such a setting, to argue for markets is not to choose efficiency over equity, nor to ignore distribution when judging levels of welfare.

While I sought to exploit the inferential leverage afforded by the theory of markets and to champion the interests of peasants, my pri- 
mary concern was with the choices of governments and the political incentives that shaped their management of Africa's agrarian economies.

Inspired by the contributions of Popkin (1979), Scott (1976), and others, the rational choice approach has escaped its bondage in economics and secured its position in development studies. Particularly in political science, rational choice approaches have gained intellectual prominence; they have been employed to study policy change during the late twentieth century debt crisis, to analyze electoral cleavages and legislative behavior in new democracies, and to account for the manner in which governments manage the risks of trade openness. Increasingly, scholars employ the approach as a mode of positive inquiry rather than as a form of moral reasoning, as a way of investigating and illuminating rather than as a way of formulating law-like generalities, and as an inductive tool rather than as a deductive method. Because of the widespread assimilation of non-cooperative game theory into the social sciences, those who apply the approach can now ground their analysis on an intellectual tradition that stands separate from, and indeed in significant opposition to, the theory of markets. The rational choice approach has provided a powerful a way of posing, and of addressing, key questions.

Why, if politicians are rational, do they make choices that are socially irrational? Why, if rational, do they behave in ways that harm the collective welfare? These are the central questions posed by Markets and States in Tropical Africa. They remain as important today as they were when the book was first published.

\section{CONCLUSION}

Africa poses the development challenge of our time. The economies of Africa remain poor. And the quality of Africa's politics impacts adversely the performance of its economies. Those of us who are scholars must continue to search out the lessons Africa is trying to teach us about the political foundations of development. Because Africa challenges us, it shapes the way we think, the way we work, and the way we perceive the world about us.

Cambridge, Massachusetts August, 2004 
xvi Preface to the 2005 Edition

\section{REFERENCES}

Bates, R. H. 1987. “Agrarian Politics." Understanding Political Development. eds., M. Weiner and S. Huntington. Boston: Little Brown.

Popkin, S. L. 1979. The Rational Peasant. Berkeley: University of California Press.

Scott, J. C. 1976. The Moral Economy of the Peasant. New Haven: Yale University Press.

World Bank, 1981. Accelerated Development in Sub-Saharan Africa: An Agenda for Action. Washington D.C.: The World Bank. 